\title{
Cochrane
}

Library

Cochrane Database of Systematic Reviews

\section{Ambulatory and short-burst oxygen for interstitial lung disease} (Review)

Sharp C, Adamali H, Millar AB

Sharp C, Adamali H, Millar AB.

Ambulatory and short-burst oxygen for interstitial lung disease.

Cochrane Database of Systematic Reviews 2016, Issue 7. Art. No.: CD011716.

DOI: 10.1002/14651858.CD011716.pub2.

www.cochranelibrary.com 
TABLE OF CONTENTS

HEADER 1

ABSTRACT

PLAIN LANGUAGE SUMMARY

SUMMARY OF FINDINGS

BACKGROUND

OBJECTIVES

METHODS

RESULTS

Figure 1.

Figure 2.

DISCUSSION

AUTHORS' CONCLUSIONS

ACKNOWLEDGEMENTS

REFERENCES

CHARACTERISTICS OF STUDIES

DATA AND ANALYSES

Analysis 1.1. Comparison 1 Ambulatory oxygen versus air, Outcome 1 Six-minute walk distance (m).

Analysis 1.2. Comparison 1 Ambulatory oxygen versus air, Outcome 2 Endurance shuttle walk test (m).

Analysis 1.3. Comparison 1 Ambulatory oxygen versus air, Outcome 3 Dyspnoea (modified Borg score).

Analysis 1.4. Comparison 1 Ambulatory oxygen versus air, Outcome 4 Oxygen saturation immediately post six-minute walk test (6MWT).

Analysis 1.5. Comparison 1 Ambulatory oxygen versus air, Outcome 5 Endurance time on cycle ergometer (s).

Analysis 1.6. Comparison 1 Ambulatory oxygen versus air, Outcome 6 Minimum saturations at 6MWT (\%).

APPENDICES

CONTRIBUTIONS OF AUTHORS

DECLARATIONS OF INTEREST

SOURCES OF SUPPORT

DIFFERENCES BETWEEN PROTOCOL AND REVIEW

INDEX TERMS 
[Intervention Review]

\section{Ambulatory and short-burst oxygen for interstitial lung disease}

Charles Sharp ${ }^{1}$, Huzaifa Adamali², Ann B Millar ${ }^{1}$

${ }^{1}$ Academic Respiratory Unit, North Bristol NHS Trust, Bristol, UK. ${ }^{2}$ Bristol Interstitial Lung Disease Service, North Bristol NHS Trust Southmead Hospital, Bristol, UK

Contact address: Charles Sharp, Academic Respiratory Unit, North Bristol NHS Trust, Southmead Hospital, Bristol, UK. Charles.sharp@bristol.ac.uk, Charles.sharp@nhs.net.

Editorial group: Cochrane Airways Group.

Publication status and date: New, published in Issue 7, 2016.

Citation: Sharp C, Adamali H, Millar AB. Ambulatory and short-burst oxygen for interstitial lung disease. Cochrane Database of Systematic Reviews 2016, Issue 7. Art. No.: CD011716. DOI: 10.1002/14651858.CD011716.pub2.

Copyright @ 2016 The Cochrane Collaboration. Published by John Wiley \& Sons, Ltd.

\section{A B S T R A C T}

\section{Background}

A large subgroup of people with interstitial lung disease (ILD) are normoxic at rest, but rapidly desaturate on exertion. This can limit exercise capacity and worsen dyspnoea. The use of ambulatory or short-burst oxygen when mobilising or during other activities, may improve exercise capacity and relieve dyspnoea.

\section{Objectives}

To determine the effects of ambulatory and short-burst oxygen therapy, separately, on exercise capacity, dyspnoea and quality of life in people who have interstitial lung disease (ILD), particularly those with idiopathic pulmonary fibrosis (IPF).

\section{Search methods}

We conducted searches in the Cochrane Airways Group Specialised Register (all years to May 2016), Cochrane Central Register of Controlled Trials (CENTRAL) (all years to May 2016), MEDLINE (Ovid) (1950 to 4th May 2016) and EMBASE (Ovid) (1974 to 4th May 2016). We also searched the reference lists of relevant studies, international clinical trial registries and respiratory conference abstracts for studies.

\section{Selection criteria}

We included randomised controlled trials (RCTs) or quasi-RCTs that compared ambulatory or short-burst oxygen with a control group in people with ILD of any origin.

\section{Data collection and analysis}

Two review authors independently selected studies for inclusion and assessed risk of bias in the included studies. We extracted data from included studies using a prepared checklist, including study characteristics and results. We used the Grading of Recommendations Assessment, Development and Evaluation (GRADE) criteria to assess the quality of the included studies.

\section{Main results}

Three studies (including 98 participants, all of whom had IPF) met the inclusion criteria of this review. These studies were conducted in hospital respiratory physiology laboratories. Two studies did not demonstrate any beneficial effect of supplemental oxygen on exercise capacity or exertional dyspnoea. Neither of these studies titrated oxygen requirements to prevent ongoing exertional desaturation. One study showed an increase in exercise capacity as assessed by endurance time with supplemental oxygen. We did not identify any studies that examined the effect of ambulatory oxygen on health-related quality of life, survival, costs or time to exacerbation or hospitalisation. No study reported any adverse events. The quality of evidence for all three studies, as assessed by GRADE criteria, was low. 


\section{Authors' conclusions}

This review found no evidence to support or refute the use of ambulatory or short burst oxygen in ILD due to the limited number of included studies and data. Further research is needed to examine the role of this treatment.

\section{PLAIN LANGUAGE SUMMARY}

\section{Use of oxygen during activities for people with lung scarring conditions}

\section{Review question}

Should oxygen be used for people with lung scarring conditions, known as interstitial lung disease (ILD), whose oxygen levels drop when they exercise?

\section{Background}

Many people with ILD have a drop in their oxygen levels when they are moving about. This is because of their lung scarring. Oxygen can be given, to be used only when people are moving about, to prevent this drop. This is called ambulatory oxygen. This may help to improve symptoms of breathlessness and their ability to exercise. It may also improve their quality of life. This Cochrane review examined the evidence for any effect of ambulatory oxygen on the ability to exercise, breathlessness and quality of life. Cochrane researchers searched the available evidence up to 4th May 2016.

\section{Study characteristics and key results}

We included only three studies, which had a total of 98 participants with ILD. All three studies compared the effects of both oxygen and air in all participants while they did an exercise test, while preventing them from knowing which treatment they were being given. Two studies showed no helpful effects on the ability to exercise or on symptoms of breathlessness. One study showed that participants could exercise for longer with oxygen. None of these studies looked at the effect of oxygen on quality of life, survival, the cost of oxygen treatment or its effects on hospital admissions. No adverse events were reported in any of the studies.

We also looked for studies of oxygen given after exercise in people with ILD ("short burst oxygen"), but did not find any studies.

\section{Quality of the evidence}

There were some problems with the way these studies were conducted. The included studies were small. Also, two studies did not make sure that the amount of oxygen given was enough to prevent a drop in oxygen levels when the participants were exercising. This could mean that they were not given enough oxygen. The overall quality of evidence in this review was low.

\section{Conclusions}

We cannot tell from these studies if ambulatory oxygen is helpful in people with ILD. More research is needed, which should look at the effect of ambulatory oxygen on exercise, breathlessness and also on quality of life in people with ILD. 


\begin{tabular}{|c|c|c|c|c|c|c|}
\hline \multicolumn{7}{|c|}{$\begin{array}{l}\text { S U M M A R Y O F F I N D I N G S } \\
\text { Summary of findings for the main comparison. Ambulatory oxygen versus air in interstitial lung disease }\end{array}$} \\
\hline \multicolumn{7}{|c|}{ 'Summary of findings' table 1: ambulatory oxygen versus air in interstitial lung disease (ILD) } \\
\hline \multicolumn{7}{|c|}{$\begin{array}{l}\text { Participant or population: people with ILD } \\
\text { Setting: Outpatient clinics and the community } \\
\text { Intervention: ambulatory oxygen } \\
\text { Comparison: placebo air }\end{array}$} \\
\hline \multirow[t]{2}{*}{ Outcomes } & \multicolumn{2}{|c|}{ Anticipated absolute effects ${ }^{\star}(95 \% \mathrm{Cl})$} & \multirow{2}{*}{$\begin{array}{l}\text { Relative effect } \\
(95 \% \mathrm{Cl})\end{array}$} & \multirow{2}{*}{$\begin{array}{l}\text { Number of par- } \\
\text { ticipants } \\
\text { (studies) }\end{array}$} & \multirow{2}{*}{$\begin{array}{l}\text { Quality of the } \\
\text { evidence } \\
\text { (GRADE) }\end{array}$} & \multirow[t]{2}{*}{ Comments } \\
\hline & Risk with air & Risk with ambulatory oxygen & & & & \\
\hline $\begin{array}{l}\text { 6-minute walk } \\
\text { test distance } \\
(6 \mathrm{MWT})(\mathrm{m})\end{array}$ & $\begin{array}{l}\text { The mean } \\
6 \mathrm{MWT}(\mathrm{m}) \text { was } \\
387\end{array}$ & $\begin{array}{l}\text { The mean } 6 \mathrm{MWT}(\mathrm{m}) \text { in the in- } \\
\text { tervention group was } 13 \text { metres } \\
\text { more ( } 36.58 \text { fewer to } 62.58 \text { more) }\end{array}$ & - & $\begin{array}{l}20 \\
(1 \mathrm{RCT})\end{array}$ & $\begin{array}{l}\oplus \oplus \odot \ominus \\
\operatorname{low} 1,2\end{array}$ & $\begin{array}{l}\text { Single small cross-over study } \\
\text { (Nishiyama 2013). }\end{array}$ \\
\hline $\begin{array}{l}\text { Endurance shut- } \\
\text { tle walk test } \\
(\text { ESWT })(m)\end{array}$ & $\begin{array}{l}\text { The mean ESWT } \\
\text { (m) was } 855\end{array}$ & $\begin{array}{l}\text { The mean ESWT }(m) \text { in the in- } \\
\text { tervention group was } 265 \text { me- } \\
\text { tres more ( } 58.39 \text { fewer to } 588.39 \\
\text { more) }\end{array}$ & - & $\begin{array}{l}6 \\
(1 \mathrm{RCT})\end{array}$ & $\begin{array}{l}\oplus \oplus \ominus \ominus \\
\operatorname{low} 1,2\end{array}$ & $\begin{array}{l}\text { Single small cross-over study (Troy } \\
\text { 2014). }\end{array}$ \\
\hline $\begin{array}{l}\text { Dyspnoea (modi- } \\
\text { fied Borg score) } \\
\text { Higher scores } \\
\text { show worse dysp- } \\
\text { noea. }\end{array}$ & $\begin{array}{l}\text { The mean dysp- } \\
\text { noea (modified } \\
\text { Borg score) was } \\
6.2\end{array}$ & $\begin{array}{l}\text { The mean dyspnoea (modified } \\
\text { Borg score) in the intervention } \\
\text { group was } 0.4 \text { units fewer ( } 1.76 \\
\text { fewer to } 0.96 \text { more) }\end{array}$ & - & $\begin{array}{l}20 \\
(1 \mathrm{RCT})\end{array}$ & $\begin{array}{l}\oplus \oplus \ominus \ominus \\
\operatorname{low} 1,2\end{array}$ & $\begin{array}{l}\text { Single small cross-over study } \\
\text { (Nishiyama 2013). } 6 / 20 \text { participants } \\
\text { had clinically important improve- } \\
\text { ments in their Borg dyspnoea scale } \\
\text { (> } 1 \text { point) after the standardised } \\
6 \text { MWT with oxygen, however } 4 / 20 \text { re- } \\
\text { ported worsening of their dyspnoea } \\
\text { (>1 point) with oxygen. Troy } 2014 \text { re- } \\
\text { ported no difference in Borg dysp- } \\
\text { noea score with oxygen compared to } \\
\text { air. }\end{array}$ \\
\hline $\begin{array}{l}\text { Endurance time } \\
\text { on constant load } \\
\text { ergometry (s) }\end{array}$ & $\begin{array}{l}\text { The mean en- } \\
\text { durance time } \\
\text { (s) was } 427.8\end{array}$ & $\begin{array}{l}\text { The mean endurance time in the } \\
\text { intervention group was } 118.7 \mathrm{sec}- \\
\text { onds more ( } 23.9 \text { more to } 213.5 \\
\text { more) }\end{array}$ & - & $72(1 \mathrm{RCT})$ & $\begin{array}{l}\oplus \oplus \odot \ominus \\
\operatorname{low} 1,2\end{array}$ & $\begin{array}{l}\text { Single cross-over study (Arizono } \\
\text { 2015). }\end{array}$ \\
\hline
\end{tabular}

*The risk in the intervention group (and its $95 \% \mathrm{Cl}$ ) is based on the assumed risk in the comparison group and the relative effect of the intervention (and its $95 \% \mathrm{Cl}$ ). 
Abbreviations: Cl: confidence interval; RR: risk ratio; OR: odds ratio; GRADE: Grading of Recommendations Assessment, Development and Evaluation; RCT: randomised controlled trial; ILD: interstitial lung disease.

\section{GRADE Working Group grades of evidence}

High quality: we are very confident that the true effect lies close to that of the estimate of the effect

Moderate quality: we are moderately confident in the effect estimate: The true effect is likely to be close to the estimate of the effect, but there is a possibility that it is substantially different

Low quality: our confidence in the effect estimate is limited: The true effect may be substantially different from the estimate of the effect

Very low quality: we have very little confidence in the effect estimate: The true effect is likely to be substantially different from the estimate of effect

1Downgraded by one for imprecision: there were wide Cls.

2Downgraded by one for indirectness: the oxygen used in this study did not correct exertional desaturation. 


\section{B A C K G R O U N D}

\section{Description of the condition}

Interstitial lung disease (ILD) is an area of growing interest within respiratory medicine. People with ILD exhibit a range of characteristic acute or chronic progressive parenchymal changes in their lung architecture. These conditions are characterised by varying degrees of pulmonary inflammation and fibrosis. While some ILDs can be rapidly reversible, a large proportion result in irreversible fibrosis, which results in the impairment of gas exchange and respiratory volumes due to alveolar distortion or destruction. This leads to hypoxaemia in some individuals, both on exertion and at rest. The most common ILD is idiopathic pulmonary fibrosis (IPF), which affects 15,000 people in the UK, with 5000 new diagnoses each year (Navaratnam 2011). IPF is a devastating condition with a median survival of three years, which is worse than that of many cancers. Although individuals with ILD are limited in their day-to-day existence by dyspnoea (breathlessness), there is a lack of data to guide the best management of symptoms (Ryerson 2012).

Over the past five years, treatments have become available for a range of ILDs, most particularly for IPF (King 2014; Richeldi 2014), and there is some promising evidence that disease progression may be slowed and fibrosis attenuated with these interventions. However, most people with IPF, and many others with ILD, will still deteriorate over time. This leads to progressive hypoxaemia, exercise limitation, cor pulmonale and ultimately death. There are currently very few interventions targeted at symptom relief that have a robust evidence base in ILD. Long-term oxygen therapy (LTOT) is used for people with resting hypoxaemia, whereas a range of antitussive agents can be given for the relief of cough; however, response to these agents is limited (NICE 2013). Dyspnoea is managed with opiates and supportive treatments, together with support from palliative care specialists.

\section{Description of the intervention}

A large subgroup of individuals with ILD do not have hypoxaemia at rest, but rapidly desaturate on exertion, by an oxygen saturation level in arterial blood $\left(\mathrm{SaO}_{2}\right)$ of greater than $4 \%$, to give $\mathrm{SaO}_{2}$ levels lower than $90 \%$. In some studies this subgroup comprises half of all participants (Lama 2003; Johnson-Warrington 2013). This desaturation can limit a person's exercise capacity but can be ameliorated by the administration of ambulatory oxygen (McDonald 1995). The aim of supplementary oxygen is to improve exercise capacity, relieve dyspnoea and improve quality of life as highlighted in recent guidelines (Hardinge 2015). Pulmonary hypertension as a complication of ILD is more common in those who desaturate (Visca 2011), and the use of oxygen may improve this. Oxygen is delivered via a nasal cannula at a variable rate from lightweight, small oxygen cylinders that contain either compressed or liquid oxygen. Use is advised during any activity likely to render the individual more dyspnoeic, this being a surrogate for hypoxaemia.

Short-burst oxygen therapy refers to the intermittent use of supplemental oxygen at home, usually for periods of about 10 to 20 minutes at a time, to relieve dyspnoea (Nandi 2003; Stevenson 2004). Short-burst oxygen therapy is offered to individuals who do not meet the criteria for LTOT but who remain dyspnoeic on minimal exertion despite other supportive therapies (BTS 2006).
It is important to differentiate between short-burst therapy and the provision of continuous oxygen with exercise, which is termed ambulatory oxygen therapy.

\section{How the intervention might work}

Ambulatory oxygen is felt to improve exercise capacity and reduce dyspnoea by correcting exertional hypoxaemia or desaturation. This may enable greater exercise training, which would improve muscular strength, and give some protection from declining lung function.

Short-burst oxygen is used as a palliative measure to relieve dyspnoea; however, there is little scientific rationale for this (Roberts 2004).

\section{Why it is important to do this review}

There are a growing number of interventions being marketed and developed for ILD, and IPF in particular, which will expand further in the coming years. These treatments have significant sideeffects and potential complications. There is a need to improve supportive care for people with ILD and to address symptom control. Currently it is unclear which interventions may be of benefit and guidelines do not recommend the routine use of oxygen in individuals without resting hypoxaemia. Despite this, the use of oxygen is widespread: in a study of pulmonary rehabilitation in ILD, $37 \%$ of participants were using some form of oxygen; however, the study report did not discriminate between LTOT and ambulatory oxygen (Johnson-Warrington 2013). Short-burst oxygen continues to be used, despite criticism of a lack of evidence for efficacy in other areas, especially in Chronic Obstructive Pulmonary Disease (COPD) (Roberts 2004). However, the most recent British Thoracic Society guidance specifically advises against its use (Hardinge 2015). This intervention is burdensome to people, with the need to carry cylinders of oxygen around when travelling, and with the stigma of oxygen tubing always apparent.

As the incidence of ILD increases (Gribbin 2006) it is vital that we offer people the most appropriate treatments informed by all the evidence available. Where this evidence is lacking, efforts should be made to address these gaps.

\section{OBJECTIVES}

To determine the effects of ambulatory and short-burst oxygen therapy, separately, on exercise capacity, dyspnoea and quality of life on people who have interstitial lung disease (ILD), particularly those with idiopathic pulmonary fibrosis (IPF).

This Cochrane review also aimed to assess, as secondary objectives, any impact of these therapies on survival, time to exacerbation of ILD that resulted in hospitalisation, and costs.

\section{METHODS}

\section{Criteria for considering studies for this review Types of studies}

We included randomised controlled trials (RCTs) of all durations that compared use of ambulatory or short-burst oxygen in adults with interstitial lung disease (ILD) with a control group. We included studies reported as full-text articles and those published in abstract form only. 


\section{Types of participants}

We included adults with a diagnosis of ILD and exertional oxygen desaturation, and all subgroups of this diagnosis, including idiopathic pulmonary fibrosis (IPF). To ensure studies examined the impact of ambulatory oxygen therapy on people with ILD and normal resting oxygen saturations, we excluded participants with the following comorbidities/characteristics: resting hypoxaemia, combined pulmonary fibrosis and emphysema.

\section{Types of interventions}

We included studies that compared ambulatory or short-burst oxygen therapy with placebo air or no intervention (including usual care/other). We noted the mode of oxygen delivery (demand/ pulse oxygen or continuous flow) and the methodology of oxygen titration, where present (symptom-based or titrated to correct desaturation).

\section{Types of outcome measures}

\section{Primary outcomes}

- Exercise capacity, as assessed by validated measures including the six-minute walking test distance and incremental shuttle walk test;

- health-related quality of life, as measured by a validated instrument;

- dyspnoea, as assessed by a validated instrument;

- serious adverse events.

\section{Secondary outcomes}

- Survival;

- time to exacerbation/hospitalisation;

- costs;

- adverse events/side-effects.

\section{Search methods for identification of studies}

\section{Electronic searches}

We searched the following databases:

- MEDLINE (Ovid) 1950 to May Week 1 2016;

- Cochrane Central Register of Controlled Trials (CENTRAL), via CRS Online, all years to May 2016;

- EMBASE (Ovid) 1974 to 2016 May 4;

- Cochrane Airways Group Specialised Register, all years up to May 2016;

- Trial registries (ClinicalTrials.gov and the World Health Organization (WHO) International Clinical Trials Registry Platform Search Portal (ICTRP)).

We have listed the search strategies in Appendix 1; Appendix 2; Appendix 3; and Appendix 4. We searched all databases from their inception to 4 May 2016, and there were no restrictions on language of publication. We checked for conference abstracts and the grey literature through the CENTRAL database.

\section{Searching other resources}

We examined the reference lists of all primary studies and review articles for additional references.
We searched for errata or retractions from included studies published in full-text form on PubMed (www.ncbi.nlm.nih.gov/ pubmed).

\section{Data collection and analysis}

\section{Selection of studies}

Two review authors ( $\mathrm{CS}$ and $\mathrm{HA}$ ) independently screened the titles and abstracts of all the potential studies identified as a result of the search for inclusion and coded them as either 'retrieve' (eligible or potentially eligible/unclear) or 'do not retrieve'. They then screened the full-text study reports/publications of the 'retrieve' group to identify studies for inclusion, and recorded the reasons for excluding any studies they considered ineligible. We collated multiple reports of the same study so that each study rather than each report was the unit of interest in the review. The selection process is illustrated by a PRISMA flow diagram and 'Characteristics of included studies' and 'Characteristics of excluded studies' tables.

\section{Data extraction and management}

Two review authors (CS and $A B M$ ) extracted data from included studies using a prepared checklist before one review author (CS) entered data into Review Manager (RevMan) (RevMan 2014). The extracted data included study characteristics (methods, participants, interventions, outcomes) and results of the included studies. We confirmed the accuracy of data entry by comparing the data presented in the systematic review with those in the study reports. A second review author (ABM) spot-checked study characteristics for accuracy against the trial report.

\section{Assessment of risk of bias in included studies}

Two review authors (CS and ABM) independently assessed the risk of bias in each included study using the criteria outlined in the Cochrane Handbook for Systematic Reviews of Interventions (Higgins 2011). We assessed the risk of bias according to the following domains, and resolved any disagreements consensus:

- random sequence generation;

- allocation concealment;

- blinding of participants and personnel;

- blinding of outcome assessment;

- incomplete outcome data;

- selective outcome reporting;

- other bias.

We judged each potential source of bias as either 'high', 'low' or 'unclear', and provided a justification for our judgement in the 'Risk of bias' section of the 'Characteristics of included studies' table. We summarised the 'Risk of bias' judgements across different studies for each of the domains listed.

\section{Measures of treatment effect}

We recorded dichotomous data as odds ratios and continuous data as mean differences or standardised mean differences.

\section{Unit of analysis issues}

We did not anticipate unit of analysis issues. 


\section{Dealing with missing data}

We attempted to contact investigators or study sponsors to verify key study characteristics and obtain missing numerical outcome data where possible (e.g. when we identified a study in abstract form only).

\section{Assessment of heterogeneity}

We planned to use the $I^{2}$ statistic to measure heterogeneity among the trials in each analysis and explore possible causes using prespecified subgroup analyses. However, there were insufficient data for meta-analysis.

\section{Assessment of reporting biases}

If we had been able to pool more than 10 trials, we would have created and examined a funnel plot to explore possible small study and publication biases. However, an insufficient number of studies met the inclusion criteria.

\section{Data synthesis}

If we had been able to combine study results, we would have used a random-effects model and performed sensitivity analyses using a fixed-effect model.

We created a 'Summary of findings' table using the following outcomes:

- exercise capacity;

- health-related quality of life;

- dyspnoea;

- survival;

- time to exacerbation/hospitalisation;

- costs;

- serious adverse events and side effects.

We used the five Grading of Recommendations Assessment, Development and Evaluation (GRADE) considerations (study limitations, consistency of effect, imprecision, indirectness and publication bias) to assess the quality of a body of evidence as it relates to the studies that contribute data to the prespecified outcomes. We used methods and recommendations described in Chapter 8.5 and Chapter 12.2 of the Cochrane Handbook for Systematic Reviews of Interventions (Higgins 2011) using GRADEpro Guideline Development Tool (GDT) software (available from www.gradepro.org). We justified all decisions to downgrade or upgrade the quality of studies using footnotes and we made comments to aid the reader's understanding of the review where necessary.

\section{Subgroup analysis and investigation of heterogeneity}

We planned to carry out a subgroup analysis of IPF compared to all other ILDs, but there were insufficient data to allow this.

\section{Sensitivity analysis}

If we had identified studies that were conducted in an unblinded fashion, we planned to undertake a sensitivity analysis to establish any impact of this on the overall findings. We planned to conduct any other sensitivity analyses that were identified following review of the included studies.

\section{RES U L T S}

\section{Description of studies}

See: Characteristics of included studies; Characteristics of excluded studies; and Characteristics of ongoing studies for more information.

\section{Results of the search}

We have summarised the literature search process in Figure 1. After removal of duplicates, we identified 483 studies from the initial searches, from which we identified 12 articles for full-text review. We did not identify any additional studies from the reference lists and there were no disagreements between the review authors. Three studies met the inclusion criteria for the review and included 98 participants (Nishiyama 2013; Troy 2014; Arizono 2015). One study was still ongoing in May 2016 (NCT02286063). We did not identify any studies that examined short burst oxygen in interstitial lung disease (ILD). We did not find any studies that examined the impact of ambulatory oxygen on health-related quality of life or any of the secondary outcome measures for this review. 
Figure 1. Study flow diagram.

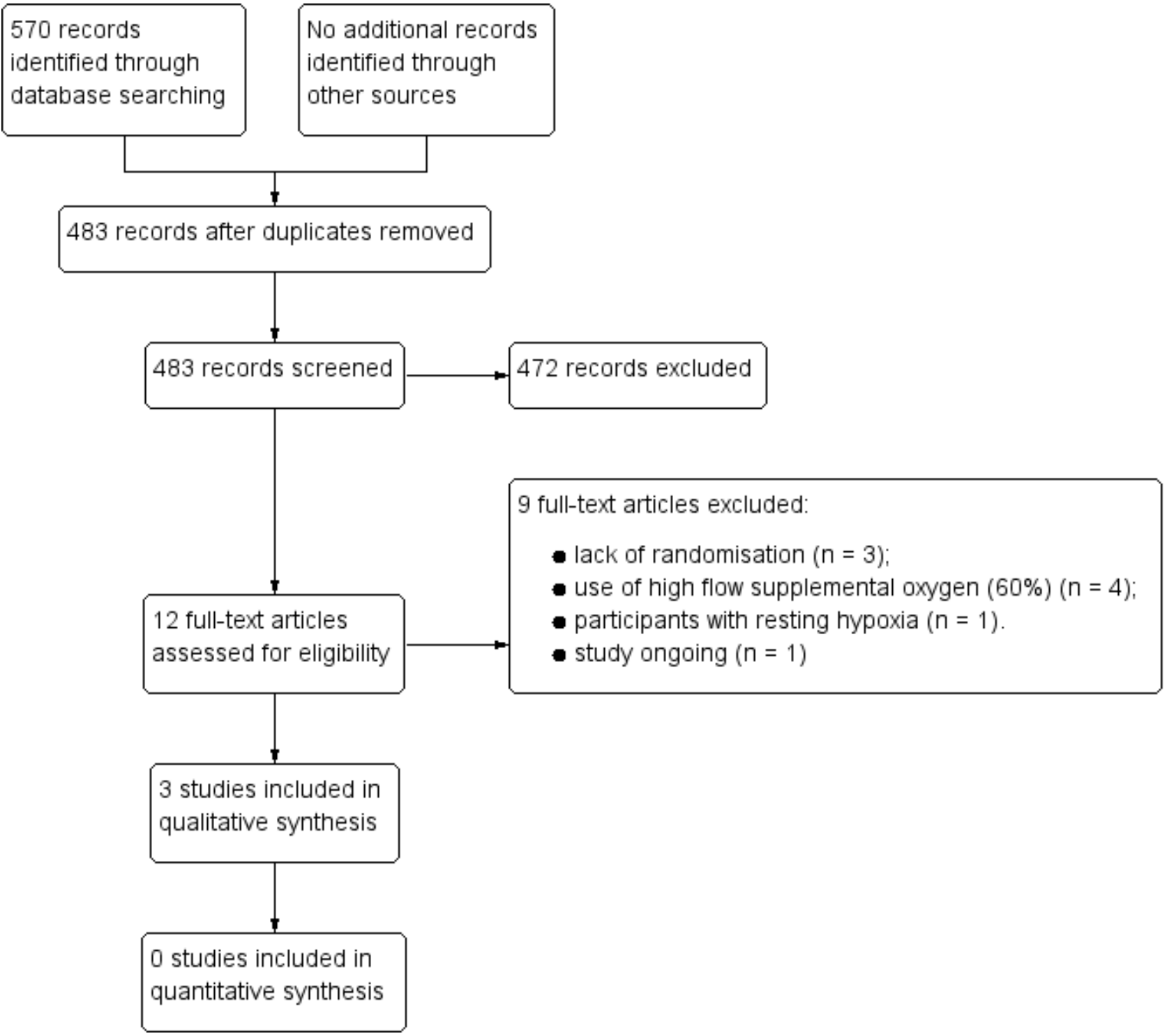

\section{Included studies}

We have presented the full details of the three included studies in the 'Characteristics of included studies' table (Nishiyama 2013; Troy 2014; Arizono 2015). All studies were conducted in hospital respiratory physiology laboratories. Two included studies were published only in abstract form (Troy 2014; Arizono 2015). Troy 2014 was a crossover randomised controlled trial (RCT) of supplemental oxygen, conducted in Sydney, Australia, that assessed the impact on exercise capacity in six participants with idiopathic pulmonary fibrosis (IPF) and exertional desaturation. Mean Forced Vital Capacity (FVC) in this study was $79.5 \%$ predicted, with mean diffusing capacity for carbon monoxide ( $D L_{C O}$ ) of $46.2 \%$. Testing included the endurance shuttle walk test (ESWT) on $3 \mathrm{~L} / \mathrm{min}$ nasal oxygen compared to medical air and also $60 \%$ supplemental oxygen while completing cycle ergometer testing. The study did not titrate oxygen flow rates to correct exertional desaturation. We only included the ESWT results in this review. Arizono 2015 was a crossover RCT that examined the impact of supplemental oxygen $(4 \mathrm{~L} / \mathrm{min})$ on endurance time at constant load ergometry in 72 participants with IPF and exertional desaturation, conducted in Shizuoka, Japan. Mean FVC in this cohort was $81.8 \%$ predicted, with $\mathrm{DL}_{\mathrm{CO}} 53.2 \%$ predicted. The study did not titrate oxygen to correct desaturation, but flow rates were high enough to achieve this. Nishiyama 2013 conducted a crossover RCT of supplemental oxygen ( $4 \mathrm{~L} / \mathrm{min}$ ) to establish its effects on dyspnoea and exercise capacity in 20 participants with IPF and exertional desaturation, with a mean FVC of $71 \%$ and $\mathrm{DL}_{\mathrm{CO}} 57 \%$. This study took place in Osaka, Japan. The study did not titrate oxygen flow rates to correct exertional desaturation.

\section{Excluded studies}

The reasons for exclusion of studies were lack of randomisation ( $\mathrm{n}$ $=3$ ), inappropriate supplemental oxygen flow rates (60\% oxygen via face mask) $(n=4)$ and participants with resting hypoxia $(n=1)$. We have presented the full details of the excluded studies in the 'Characteristics of excluded studies' table. 


\section{Risk of bias in included studies}

We have summarised the 'Risk of bias' findings in Figure 2.

Figure 2. 'Risk of bias' summary: review authors' judgements about each 'Risk of bias' item for each included study.

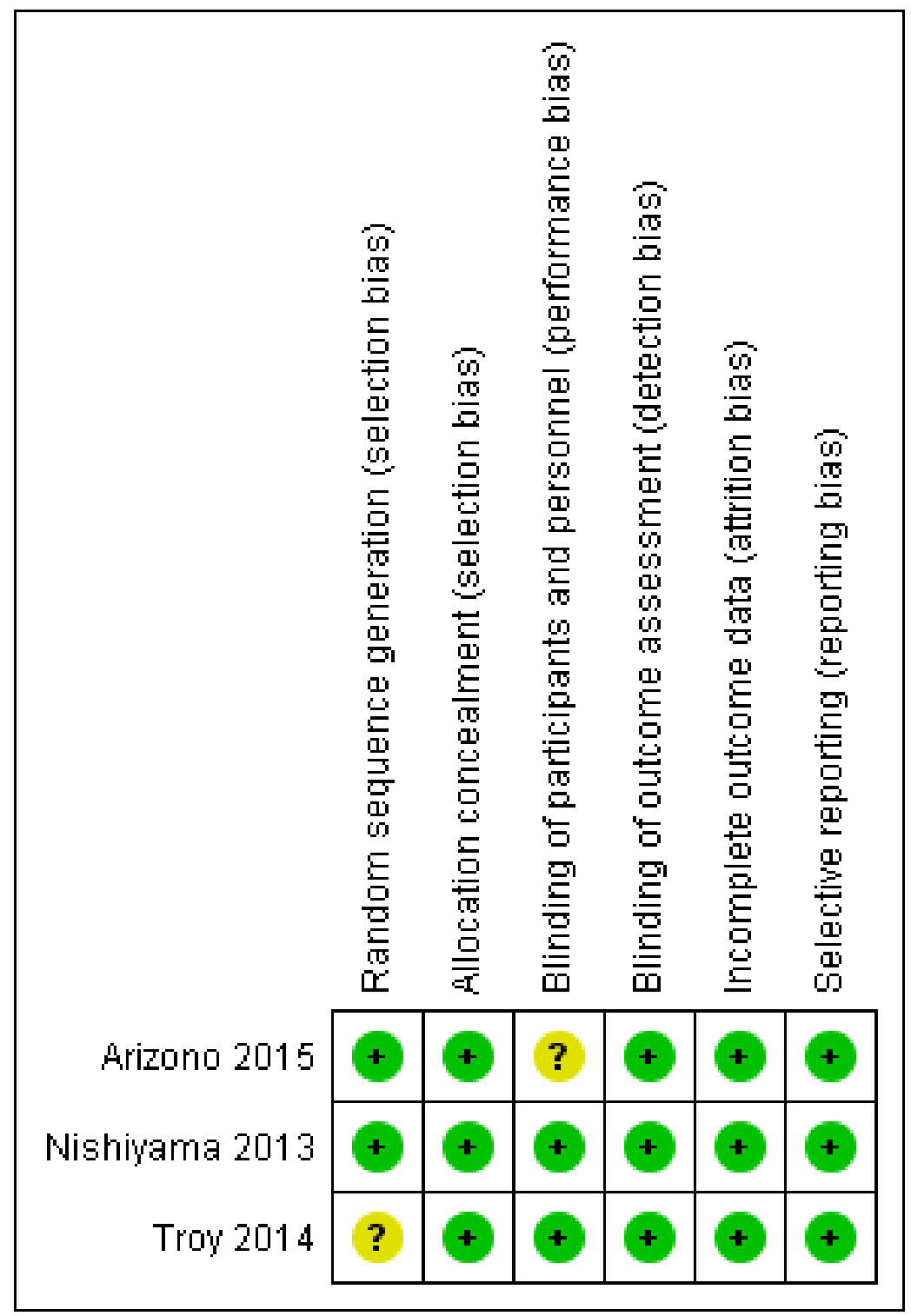

\section{Allocation}

All studies were crossover designs, therefore all participants performed exercise testing under both conditions. All included studies reported random sequence of testing, with sequence generation by coin toss for Arizono 2015 and Nishiyama 2013. Sequence generation for Troy 2014 was unclear, however randomisation was stated.

\section{Blinding}

All studies reported double-blinding, with placebo air used at the same flow rate as that used for oxygen. The means of blinding to the intervention was unclear for Arizono 2015 and Troy 2014. Nishiyama 2013 covered the cylinders used during testing to blind both participants and investigators. All studies had a cross-over design such that all participants received both air and oxygen. Arizono 2015 and Troy 2014 used standardised testing, which minimises the chance of detection bias, while Nishiyama 2013 stated that results were not available to investigators until the study was completed.

\section{Incomplete outcome data}

All participants completed all elements of testing in both studies.

\section{Selective reporting}

All included studies reported all data. 


\section{Other potential sources of bias}

We did not identify any other potential sources of bias.

\section{Effects of interventions}

See: Summary of findings for the main comparison Ambulatory oxygen versus air in interstitial lung disease

The 'Summary of findings' table demonstrates the narrative findings of the review (Summary of findings for the main comparison). There were insufficient data for meta-analysis.

\section{Exercise capacity}

Nishiyama 2013 did not demonstrate any increase in walking distance at the 6-minute walk test (6MWT) (oxygen: $400 \pm 80 \mathrm{~m}$; air: $387 \pm 80 \mathrm{~m}$; Difference $13.0 \mathrm{~m}$ (95\% confidence interval $(\mathrm{Cl})$ $-36.58,62.58 \mathrm{~m}) \mathrm{P}=0.61$; reported in paper from an unpaired t-test; Analysis 1.1). Troy 2014 did not demonstrate a significant increase in ESWT distance (oxygen: $1120 \pm 544 \mathrm{~m}$; air: $855 \pm 446 \mathrm{~m}$; difference $265 \mathrm{~m}(95 \% \mathrm{Cl}-58.39,588.39 \mathrm{~m}) \mathrm{P}=0.14$; Analysis 1.2). Arizono 2015 showed an increase in endurance time at constant load ergometry (oxygen: $546.5 \pm 326.8 \mathrm{~s}$; air: $427.8 \pm 242.4 \mathrm{~s}$; difference $118.7 \mathrm{~s}$ ( $95 \%$ $\mathrm{Cl} 24.72$ to $212.68 \mathrm{~s}) \mathrm{P}<0.05$; reported from an unpaired t-test; Analysis 1.5).

\section{Dyspnoea}

Nishiyama 2013 was designed to assess the impact of supplemental oxygen on dyspnoea. There were no significant differences in Borg dyspnoea scores following the 6MWT between $4 \mathrm{~L} / \mathrm{min}$ oxygen and medical air (difference $-0.4(95 \% \mathrm{Cl}-1.76$ to 0.96$)$ (Analysis 1.3). The study authors reported that $6 / 20$ participants had clinically important improvements in Borg scores (more than one point) on oxygen, however, $4 / 20$ reported worsening of dyspnoea (more than one point). Troy 2014 reported no difference in Borg scores between groups on the ESWT.

\section{Health-related quality of life}

We did not identify any studies that examined the effect of ambulatory oxygen on health-related quality of life.

\section{Adverse events}

No serious adverse events or side effects were reported.

Nishiyama 2013 reported oxygen saturation following the 6MWT and this indicated that the supplemental oxygen had increased oxygen saturation after the test (Analysis 1.4). Arizono 2015 reported minimum oxygen saturations during constant load ergometry and this showed that minimum levels were higher with oxygen (oxygen $92.7 \pm 4.1 \%$; air: $87.6 \pm 5.6 \%$; difference $5.1 \%$ (95\% $\mathrm{Cl} 3.5,6.7 \%) \mathrm{P}<0.05$; Analysis 1.6).

\section{Other outcomes}

No studies were identified reporting the other outcome measures of survival, costs and time to hospitalisation or exacerbation.

\section{DISCUSSION}

\section{Summary of main results}

This Cochrane review included three randomised controlled trials (RCTs) that compared supplemental (ambulatory) oxygen to medical air in participants with interstitial lung disease (ILD), and all only recruited participants with idiopathic pulmonary fibrosis (IPF). Ambulatory oxygen did not result in improved exercise capacity or dyspnoea in two included studies. However, neither of these studies adequately titrated oxygen requirements to the correct exertional desaturation, which may have altered their findings. The remaining included study did demonstrate an increase in endurance time at constant load cycle ergometry with oxygen and also showed that oxygen saturations had been improved by the intervention during the test. Additionally, none of these studies assessed reproducibility of the response to supplementary oxygen.

To date there are insufficient data to draw conclusions regarding the effectiveness of ambulatory oxygen to improve exercise capacity or exertional dyspnoea in people with ILD. We note the registration of a larger scale RCT of ambulatory oxygen in people with fibrotic ILD and await findings from this study.

\section{Overall completeness and applicability of evidence}

These studies were all conducted in people with IPF. We did not find any studies of ambulatory oxygen in other forms of ILD.

To our knowledge, there are no studies that examine short-burst oxygen use in people with ILD, which has implications for clinical practice. This treatment is available and is used for patients with ILD, but guidelines advise against this (Hardinge 2015). The lack of evidence in addition to current guidelines should prompt a review of its availability.

\section{Quality of the evidence}

The overall quality of included studies was low according to the GRADE criteria. There is a lack of data from well-designed, appropriately-randomised studies that address the question of use of ambulatory oxygen in people with ILD. This is an area that requires RCTs with outcome measures that include exercise capacity, dyspnoea, quality of life and hospital admission. There were no other identified sources of bias in these data.

\section{Potential biases in the review process}

There were no identified sources of bias in the review process.

\section{Agreements and disagreements with other studies or reviews}

Two small, retrospective observational studies that did titrate oxygen requirements to correct desaturation demonstrated improvements in walking distance (Visca 2011; Frank 2012), and one of these studies also indicated improvements in Borg scores (Visca 2011). This suggests that adequate titration of oxygen requirements may be an important element of implementation of ambulatory oxygen. However, this requires further exploration.

\section{AUTHORS' CONCLUSIONS}

\section{Implications for practice}

The previously assumed benefit to people with interstitial lung disease (ILD) from ambulatory oxygen has not been demonstrated by this review of the current evidence. Two included studies did not appropriately titrate oxygen delivery and did not demonstrate improved exercise capacity or dyspnoea, while another study did 
show some benefit in exercise endurance. There were no studies of short burst oxygen in ILD.

\section{Implications for research}

Larger scale, multicentre studies are required to explore the potential benefit of ambulatory oxygen in ILD in terms of exercise capacity, health-related quality of life and dyspnoea, while also examining its effects on survival and hospital admission. It would also be useful to examine the reproducibility of any benefits seen with supplementary oxygen. There are ethical and safety difficulties associated with providing a placebo air cylinder to a frail population in a community setting, as well as the risks of unlabelled oxygen cylinders, and this may mandate studies without optimal blinding.

\section{A C K N OWLEDGEMENTS}

Liz Stovold, the Information Specialist at the Cochrane Airways Group, devised the literature search and ran the literature searches in the review.

Chris Cates was the Editor for this Cochrane review and commented critically on the review.

We have based the 'Background' and 'Methods' sections of this review on a standard template used by the Cochrane Airways Group.

This project was supported by the National Institute for Health Research (NIHR), via Cochrane Infrastructure funding to the Cochrane Airways Group. The views and opinions expressed therein are those of the review authors and do not necessarily reflect those of the Systematic Reviews Programme, the NIHR, the National Health Service (NHS) or the Department of Health. 


\section{RE F E R E N C E S}

\section{References to studies included in this review}

Arizono 2015 \{published data only\}

Arizono S, Taniguchi H, Sakamoto K, Kondoh Y, Kimura T, Kataoka K, et al. Benefits of supplemental oxygen on exercise capacity in IPF patients with exercise-induced hypoxemia. European Respiratory Journal. 2015; Vol. 46, issue S59:OA4971.

Nishiyama 2013 \{published data only\} Nishiyama O, Miyajima H, Fukai Y, Yamazaki R, Satoh R, Yamagata T, et al. Effect of ambulatory oxygen on exertional dyspnoea in IPF patients without resting hypoxemia. Respiratory Medicine 2013;107(8):1241-6.

\section{Troy 2014 \{published data only\}}

Troy L, Young I, Munoz P, Taylor N, Webster S, Lau E, et al. Does supplemental oxygen increase exercise endurance in patients with idiopathic pulmonary fibrosis?. Respirology. 2014; Vol. 19:95.

\section{References to studies excluded from this review}

Bye 1982 \{published data only\}

Bye PT, Anderson SD, Woolcock AJ, Young IH, Alison JA. Bicycle endurance performance of patients with interstitial lung disease breathing air and oxygen. American Review of Respiratory Disease 1982;126(6):1005-12.

Frank 2012 \{published data only\}

Frank RC, Hicks S, Duck AM, Spencer L, Leonard CT, Barnett E. Ambulatory oxygen in idiopathic pulmonary fibrosis: of what benefit?. European Respiratory Journal 2012;40(1):269-70.

\section{Harris-Eze 1994 \{published data only\}}

Harris-Eze AO, Sridhar G, Clemens RE, Gallagher CG, Marciniuk DD. Oxygen improves maximal exercise performance in interstitial lung disease. American Journal of Respiratory and Critical Care Medicine 1994;150(6):1616-22.

\section{Leach 1992 \{published data only\}}

Leach RM, Davidson AC, Chinn S, Twort CH, Cameron IR, Bateman NT. Portable liquid oxygen and exercise ability in severe respiratory disability. Thorax 1992;47(10):781-9.

\section{Pouwels-Fry 2008 \{published data only\}}

Pouwels-Fry S, Pouwels S, Fournier C, Duchemin A, TillieLeblond I, Le Tourneau T, et al. Effects of oxygen on exerciseinduced increase of pulmonary arterial pressure in idiopathic pulmonary fibrosis. Sarcoidosis, Vasculitis, and Diffuse Lung Diseases 2008;25(2):133-9.

\section{Schaeffer 2015 \{published data only\}}

Schaeffer MR, Ryerson CJ, Wilkie SS, Ramsook AH, MolgatSeon Y, Khalil N, et al. Acute effects of supplemental oxygen on dyspnea, exercise endurance and respiratory neural drive in patients with fibrotic interstitial lung disease. American Journal of Respiratory and Critical Care Medicine. 2015; Vol. 191, issue Meeting Abstracts:A4400.
Tryfon 2003 \{published data only\}

Tryfon MS, Mavrofridas E, Ilonidis G, Patakas D, Tryfon SM, Mavrofridis E. Cardiopulmonary effects of exercise, before and after oxygen delivery, in patients with usual interstitial pneumonia [Abstract]. European Respiratory Journal. 2003; Vol. 22:P639.

\section{Visca 2011 \{published data only\}}

Visca D, Montgomery A, de Lauretis A, Sestini P, Soteriou H, Maher TM, et al. Ambulatory oxygen in interstitial lung disease. European Respiratory Journal 2011;38(4):987-90.

\section{References to ongoing studies \\ NCT02286063 \{unpublished data only\}}

Ambulatory Oxygen in Fibrotic Lung Disease (FLD) (AmbOx) (AmbOx). //clinicaltrials.gov/ct2/show/NCT02286063 accessed 29 June 2016

\section{Additional references}

\section{BTS 2006}

British Thoracic Society (BTS) Working Group on Home Oxygen Services. Clinical component for the home oxygen service in England and Wales. www.brit-thoracic.org.uk/ document-library/clinical-information/oxygen/home-oxygenguideline-\%28adults\%29/bts-home-oxygen-in-adults-clinicalcomponent/ (accessed 20 January 2015).

\section{Gribbin 2006}

Gribbin J, Hubbard RB, Le Jeune I, Smith CJ, West J, Tata LJ. Incidence and mortality of idiopathic pulmonary fibrosis and sarcoidosis in the UK. Thorax 2006;61(11):980-5.

\section{Hardinge 2015}

Hardinge M, Annandale J, Bourne S, Cooper B, Evans A, Freeman D, et al. British Thoracic Society Home Oxygen Guideline Development Group, on behalf of the British Thoracic Society Standards of Care Committee. British Thoracic Society guidelines for home oxygen use in adults. Thorax 2015;70 Suppl 1:i1-i43.

\section{Higgins 2011}

Higgins JPT, Green S (editors). Cochrane Handbook for Systematic Reviews of Interventions Version 5.1.0 [updated March 2011]. The Cochrane Collaboration, 2011. Available from www.cochrane-handbook.org.

\section{Johnson-Warrington 2013}

Johnson-Warrington V, Williams J, Bankart J, Steiner M, Morgan M, Singh S. Pulmonary rehabilitation and interstitial lung disease: aiding the referral decision. Journal of Cardiopulmonary Rehabilitation and Prevention 2013;33(3):189-95.

\section{King 2014}

King TE Jr, Bradford WZ, Castro-Bernardini S, Fagan EA Glaspole I, Glassberg MK, et al. A phase 3 trial of pirfenidone in 
patients with idiopathic pulmonary fibrosis. The New England Journal of Medicine 2014;370(22):2083-92.

\section{Lama 2003}

Lama VN, Flaherty KR, Toews GB, Colby TV, Travis WD, Long Q, et al. Prognostic value of desaturation during a 6-minute walk test in idiopathic interstitial pneumonia. American Journal of Respiratory and Critical Care Medicine 2003;168(9):1084-90.

\section{McDonald 1995}

McDonald CF, Blyth CM, Lazarus MD, Marschner I, Barter CE. Exertional oxygen of limited benefit in patients with chronic obstructive pulmonary disease and mild hypoxaemia. American Journal of Respiratory and Critical Care Medicine 1995;152(5 Pt 1):1616-9.

\section{Nandi 2003}

Nandi K, Smith AA, Crawford A, MacRae KD, Garrod R, See WA, et al. Oxygen supplementation before or after submaximal exercise in patients with chronic obstructive pulmonary disease. Thorax 2003;58(8):670-3.

\section{Navaratnam 2011}

Navaratnam V, Fleming KM, West J, Smith CJ, Jenkins RG, Fogarty $\mathrm{A}$, et al. The rising incidence of idiopathic pulmonary fibrosis in the U.K. Thorax 2011;66(6):462-7.

\section{NICE 2013}

National Institute for Health and Care Excellence. Idiopathic pulmonary fibrosis: the diagnosis and management of suspected idiopathic pulmonary fibrosis. NICE guidelines [CG163]. Published June 2013. www.nice.org.uk/guidance/ cg163 (accessed 20 January 2015).

\section{CHARACTERISTICS OF STUDIES}

Characteristics of included studies [ordered by study ID]

\section{RevMan 2014 [Computer program]}

The Nordic Cochrane Centre, The Cochrane Collaboration. Review Manager (RevMan). Version 5.3. Copenhagen: The Nordic Cochrane Centre, The Cochrane Collaboration, 2014.

\section{Richeldi 2014}

Richeldi L, du Bois RM, Raghu G, Azuma A, Brown KK, Costabel U, et al. Efficacy and safety of nintedanib in idiopathic pulmonary fibrosis. The New England Journal of Medicine 2014;370(22):2071-82

\section{Roberts 2004}

Roberts CM. Short burst oxygen therapy for relief of breathlessness in COPD. Thorax 2004;59(8):638-40.

\section{Ryerson 2012}

Ryerson CJ, Donesky D, Pantilat SZ, Collard HR. Dyspnea in idiopathic pulmonary fibrosis: a systematic review. Journal of Pain and Symptom Management 2012;43(4):771-82.

\section{Stevenson 2004}

Stevenson NJ, Calverley PM. Effect of oxygen on recovery from maximal exercise in patients with chronic obstructive pulmonary disease. Thorax 2004;59(8):668-72.

\section{References to other published versions of this review Sharp 2015}

Sharp C, Adamali H, Millar AB. Ambulatory and shortburst oxygen for interstitial lung disease. Cochrane Database of Systematic Reviews 2015, Issue 6. [DOI: 10.1002/14651858.CD011716]

Arizono 2015

\begin{tabular}{ll}
\hline Methods & Randomized cross-over study \\
\hline Participants & $\begin{array}{l}72 \text { participants with idiopathic pulmonary fibrosis (IPF) and exertional desaturation to }<89 \% \text { on } 6 \mathrm{MWT} \\
\text { in room air. Exclusion criteria were resting hypoxaemia and an inability to complete exercise testing }\end{array}$ \\
\hline Interventions & Ambulatory oxygen versus ambulatory air via portable cylinder at $4 \mathrm{~L} /$ min intranasally \\
\hline Outcomes & Constant load ergometry test evaluating endurance time and minimum oxygen saturations \\
\hline Notes & Conducted in hospital respiratory physiology laboratory in Shizuoka, Japan
\end{tabular}

Risk of bias

\begin{tabular}{lll}
\hline Bias & Authors' judgement & Support for judgement \\
\hline $\begin{array}{l}\text { Random sequence genera- } \\
\text { tion (selection bias) }\end{array}$ & Low risk & Randomisation was by coin toss \\
\hline $\begin{array}{l}\text { Allocation concealment } \\
\text { (selection bias) }\end{array}$ & Low risk & The crossover design negates this \\
\hline \hline
\end{tabular}


Arizono 2015 (Continued)
Blinding of participants
Unclear risk
Blinding was unclear: "randomized cross-over trial" and personnel (performance bias)

All outcomes

\begin{tabular}{|c|c|c|}
\hline $\begin{array}{l}\text { Blinding of outcome as- } \\
\text { sessment (detection bias) } \\
\text { All outcomes }\end{array}$ & Low risk & $\begin{array}{l}\text { Testing was standardised, however the study authors did not explicitly state } \\
\text { that they performed blinding }\end{array}$ \\
\hline
\end{tabular}

Incomplete outcome data Low risk $\quad$ All participants completed testing
(attrition bias)

All outcomes

Selective reporting (re- Low risk The study authors reported all data
porting bias)

porting bias)

Nishiyama 2013

\begin{tabular}{ll}
\hline Methods & Double blind, placebo controlled, randomised crossover study \\
\hline Participants & $\begin{array}{l}20 \text { participants with IPF and exertional desaturation to }<88 \% \text { on } 6 \mathrm{MWT} \text { in room air. Exclusion criteria } \\
\text { were resting hypoxaemia and an inability to complete exercise testing }\end{array}$ \\
\hline Interventions & Ambulatory oxygen versus ambulatory air via portable cylinder at 4 L/min using a demand system \\
\hline Outcomes & Distance at 6MWT \\
\hline Notes & Conducted in hospital respiratory physiology laboratory in Osaka, Japan
\end{tabular}

\section{Risk of bias}

\begin{tabular}{|c|c|c|}
\hline Bias & Authors' judgement & Support for judgement \\
\hline $\begin{array}{l}\text { Random sequence genera- } \\
\text { tion (selection bias) }\end{array}$ & Low risk & Randomisation was by coin toss \\
\hline $\begin{array}{l}\text { Allocation concealment } \\
\text { (selection bias) }\end{array}$ & Low risk & Crossover design negates this \\
\hline $\begin{array}{l}\text { Blinding of participants } \\
\text { and personnel (perfor- } \\
\text { mance bias) } \\
\text { All outcomes }\end{array}$ & Low risk & $\begin{array}{l}\text { "...each cylinder was covered with an identical sack so that the subjects and } \\
\text { physicians remained blinded to the treatment group." }\end{array}$ \\
\hline $\begin{array}{l}\text { Blinding of outcome as- } \\
\text { sessment (detection bias) } \\
\text { All outcomes }\end{array}$ & Low risk & $\begin{array}{l}\text { "...baseline oxygen saturation and heart rate were recorded by the coordi- } \\
\text { nator; these results were concealed from the physicians who performed the } \\
\text { tests." }\end{array}$ \\
\hline $\begin{array}{l}\text { Incomplete outcome data } \\
\text { (attrition bias) } \\
\text { All outcomes }\end{array}$ & Low risk & All participants completed testing \\
\hline
\end{tabular}

Selective reporting (re- Low risk $\quad$ The study authors reported all data
porting bias)


Troy 2014

\begin{tabular}{ll}
\hline Methods & Double blind, placebo controlled, randomised crossover study \\
\hline Participants & $\begin{array}{l}\text { Six participants with IPF, resting normoxia and exercise desaturation. Exclusion criteria were resting } \\
\text { hypoxaemia and an inability to complete exercise testing }\end{array}$ \\
\hline Interventions & $\begin{array}{l}\text { Supplemental oxygen (60\% for cardiopulmonary exercise testing, } 3 \mathrm{~L} / \mathrm{min} \text { for endurance walk (deliv- } \\
\text { ered via light-weight cylinder)) compared to medical air }\end{array}$ \\
\hline Outcomes & Cardiopulmonary exercise test and distance at endurance shuttle walk test (ESWT) (m) \\
\hline Notes & Conducted in hospital respiratory physiology laboratory in Sydney, Australia
\end{tabular}

\section{Risk of bias}

\begin{tabular}{|c|c|c|}
\hline Bias & Authors' judgement & Support for judgement \\
\hline $\begin{array}{l}\text { Random sequence genera- } \\
\text { tion (selection bias) }\end{array}$ & Unclear risk & $\begin{array}{l}\text { Sequence generation was unclear: "subjects completed two shuttle en- } \\
\text { durance walk tests randomised to } 3 \mathrm{~L} / \mathrm{min} \text { oxygen or medical air in a ran- } \\
\text { domised cross-over double blinded fashion." }\end{array}$ \\
\hline $\begin{array}{l}\text { Allocation concealment } \\
\text { (selection bias) }\end{array}$ & Low risk & Crossover design negates this \\
\hline $\begin{array}{l}\text { Blinding of participants } \\
\text { and personnel (perfor- } \\
\text { mance bias) } \\
\text { All outcomes }\end{array}$ & Low risk & The study authors reported double blinding (see above) \\
\hline $\begin{array}{l}\text { Blinding of outcome as- } \\
\text { sessment (detection bias) } \\
\text { All outcomes }\end{array}$ & Low risk & $\begin{array}{l}\text { The ESWT is a standardised test. The trial authors did not explicitly state that } \\
\text { they performed blinding }\end{array}$ \\
\hline $\begin{array}{l}\text { Incomplete outcome data } \\
\text { (attrition bias) } \\
\text { All outcomes }\end{array}$ & Low risk & All participants completed the study \\
\hline $\begin{array}{l}\text { Selective reporting (re- } \\
\text { porting bias) }\end{array}$ & Low risk & The study authors reported all data \\
\hline
\end{tabular}

Abbreviations: IPF: idiopathic pulmonary fibrosis; ESWT: endurance shuttle walk test; 6MWT: 6-minute walk test; L/min: litres per minute.

Characteristics of excluded studies [ordered by study ID]

\begin{tabular}{ll}
\hline Study & Reason for exclusion \\
\hline Bye 1982 & $\begin{array}{l}\text { The participants used supplemental oxygen at } 60 \% \text { and not from a cylinder supply, therefore they } \\
\text { did not use ambulatory oxygen }\end{array}$ \\
\hline Frank 2012 & This study was neither randomised nor used a blinded design \\
\hline Harris-Eze 1994 & $\begin{array}{l}\text { The participants used supplemental oxygen at } 60 \% \text { and not from a cylinder supply, therefore they } \\
\text { did not use ambulatory oxygen }\end{array}$ \\
\hline
\end{tabular}




\begin{tabular}{ll}
\hline Study & Reason for exclusion \\
\hline Leach 1992 & This study did not separately report ILD results and participants had resting hypoxia \\
\hline Pouwels-Fry 2008 & This study was neither randomised nor used a blinded design \\
\hline Schaeffer 2015 & $\begin{array}{l}\text { The participants used supplemental oxygen at } 60 \% \text { and not from a cylinder supply, therefore they } \\
\text { did not use ambulatory oxygen }\end{array}$ \\
\hline Tryfon 2003 & $\begin{array}{l}\text { The participants used supplemental oxygen at } 60 \% \text { and not from a cylinder supply, therefore they } \\
\text { did not use ambulatory oxygen }\end{array}$ \\
\hline Visca 2011 & This study used an observational, retrospective design \\
\hline
\end{tabular}

Abbreviations: ILD: interstitial lung disease.

Characteristics of ongoing studies [ordered by study ID]

\section{NCT02286063}

\begin{tabular}{ll}
\hline Trial name or title & Ambox study \\
\hline Methods & Crossover randomised controlled trial \\
\hline Participants & $\begin{array}{l}\text { Participants with idiopathic pulmonary fibrosis (IPF) or another fibrotic interstitial lung disease } \\
\text { (ILD) with desaturation on six-minute walk test (6MWT) }\end{array}$ \\
\hline Interventions & Ambulatory oxygen versus no oxygen \\
\hline Outcomes & Quality of life: change in K-BILD \\
& $\begin{array}{l}\text { Secondary outcomes including dyspnoea (San Diego shortness of breath questionnaire), daily ac- } \\
\text { tivity }\end{array}$ \\
\hline Starting date & August 2014 \\
\hline Contact information & d.visca@rbht.nhs.uk \\
\hline
\end{tabular}

Notes

Abbreviations: IPF: idiopathic pulmonary fibrosis: ILD: interstitial lung disease; 6MWT: 6-minute walk test; K-BILD: King's Brief Interstitial Lung Disease tool.

\section{DATA AND ANALYSES}

\section{Comparison 1. Ambulatory oxygen versus air}

\begin{tabular}{lllll}
\hline Outcome or subgroup title & No. of studies & $\begin{array}{l}\text { No. of partici- } \\
\text { pants }\end{array}$ & Statistical method & Effect size \\
\hline 1 Six-minute walk distance $(\mathrm{m})$ & 1 & & $\begin{array}{l}\text { Mean Difference (Fixed, 95\% } \\
\text { Cl) }\end{array}$ & $13.0[-36.58,62.58]$ \\
\hline
\end{tabular}




\begin{tabular}{|c|c|c|c|c|}
\hline Outcome or subgroup title & No. of studies & $\begin{array}{l}\text { No. of partici- } \\
\text { pants }\end{array}$ & Statistical method & Effect size \\
\hline 2 Endurance shuttle walk test $(\mathrm{m})$ & 1 & & $\begin{array}{l}\text { Mean Difference (Fixed, 95\% } \\
\mathrm{Cl} \text { ) }\end{array}$ & $\begin{array}{l}265.0[-58.39 \\
588.39]\end{array}$ \\
\hline 3 Dyspnoea (modified Borg score) & 1 & & $\begin{array}{l}\text { Mean Difference (Fixed, 95\% } \\
\mathrm{Cl} \text { ) }\end{array}$ & $-0.4[-1.76,0.96]$ \\
\hline $\begin{array}{l}4 \text { Oxygen saturation immediately } \\
\text { post six-minute walk test (6MWT) }\end{array}$ & 1 & & $\begin{array}{l}\text { Mean Difference (Fixed, 95\% } \\
\mathrm{Cl} \text { ) }\end{array}$ & Totals not selected \\
\hline $\begin{array}{l}5 \text { Endurance time on cycle ergome- } \\
\operatorname{ter}(\mathrm{s})\end{array}$ & 1 & & $\begin{array}{l}\text { Mean Difference (Fixed, 95\% } \\
\mathrm{Cl} \text { ) }\end{array}$ & $\begin{array}{l}118.7[24.72 \\
212.68]\end{array}$ \\
\hline 6 Minimum saturations at $6 \mathrm{MWT}(\%)$ & 1 & & $\begin{array}{l}\text { Mean Difference (Fixed, 95\% } \\
\mathrm{Cl} \text { ) }\end{array}$ & $5.1[3.50,6.70]$ \\
\hline
\end{tabular}

Analysis 1.1. Comparison 1 Ambulatory oxygen versus air, Outcome 1 Six-minute walk distance (m).

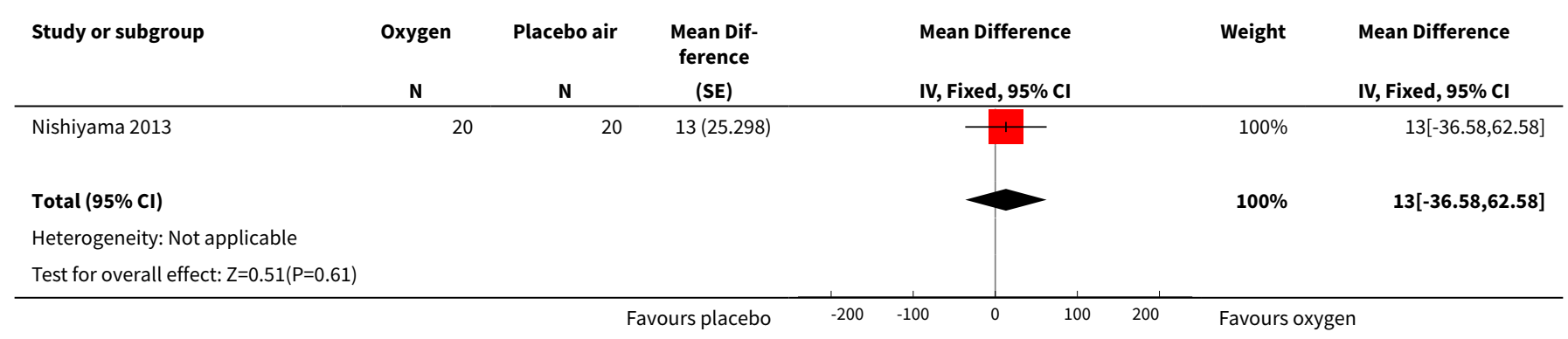

Analysis 1.2. Comparison 1 Ambulatory oxygen versus air, Outcome 2 Endurance shuttle walk test (m).

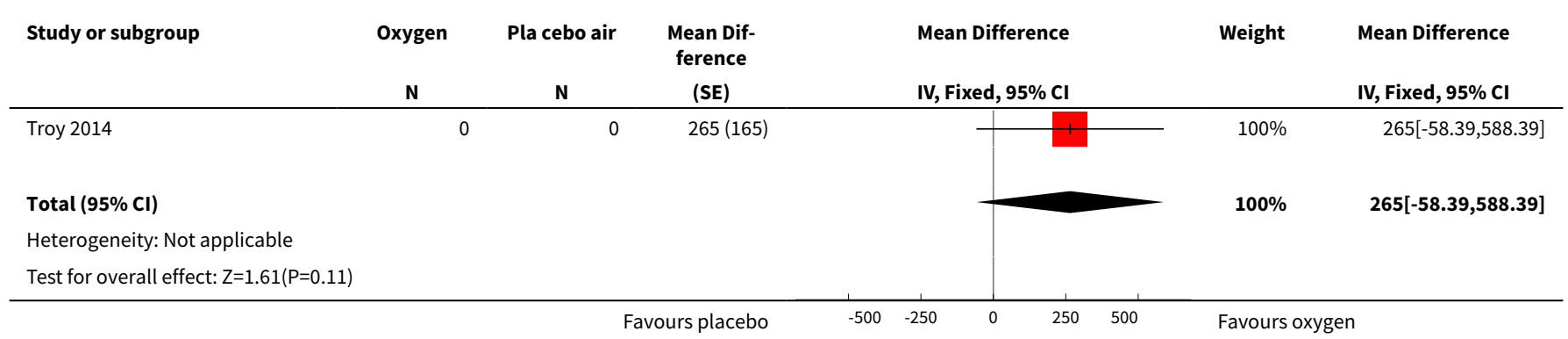

Analysis 1.3. Comparison 1 Ambulatory oxygen versus air, Outcome 3 Dyspnoea (modified Borg score).

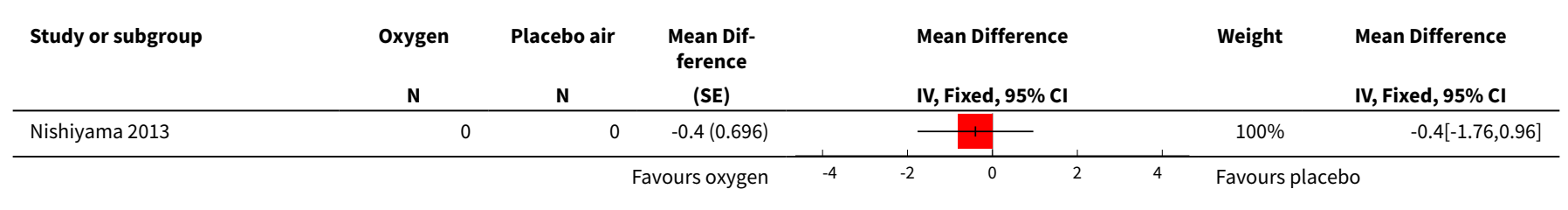




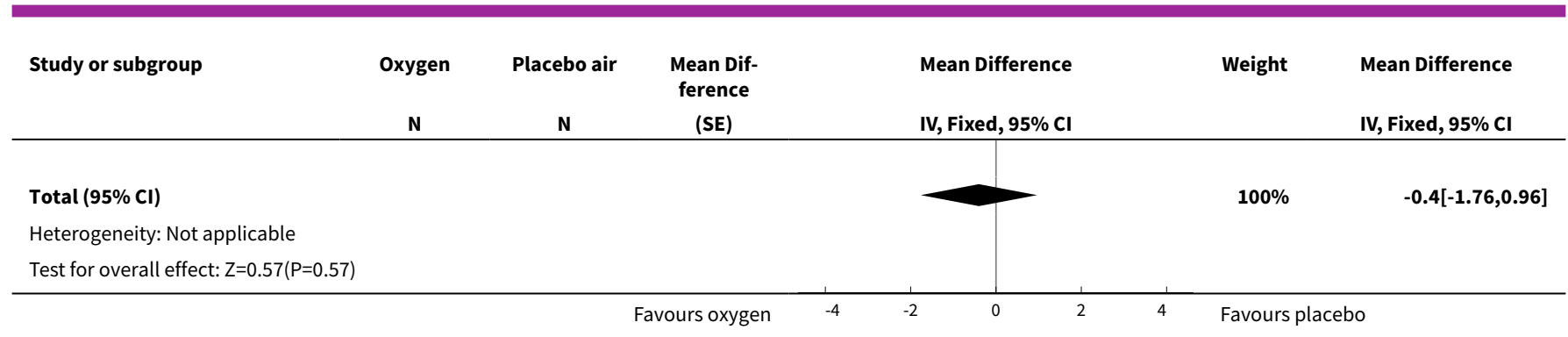

Analysis 1.4. Comparison 1 Ambulatory oxygen versus air, Outcome 4 Oxygen saturation immediately post six-minute walk test (6MWT).

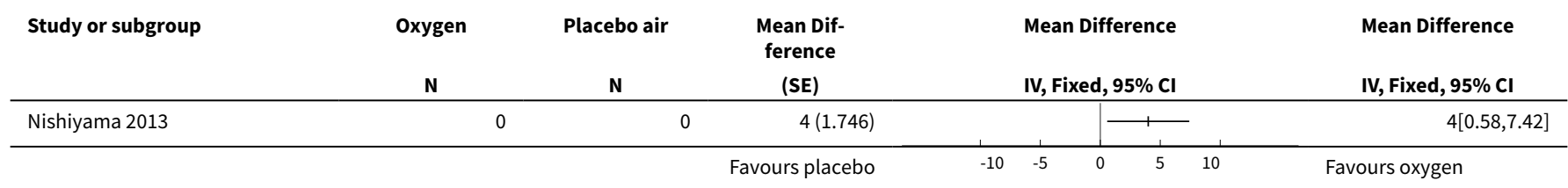

Analysis 1.5. Comparison 1 Ambulatory oxygen versus air, Outcome 5 Endurance time on cycle ergometer (s).

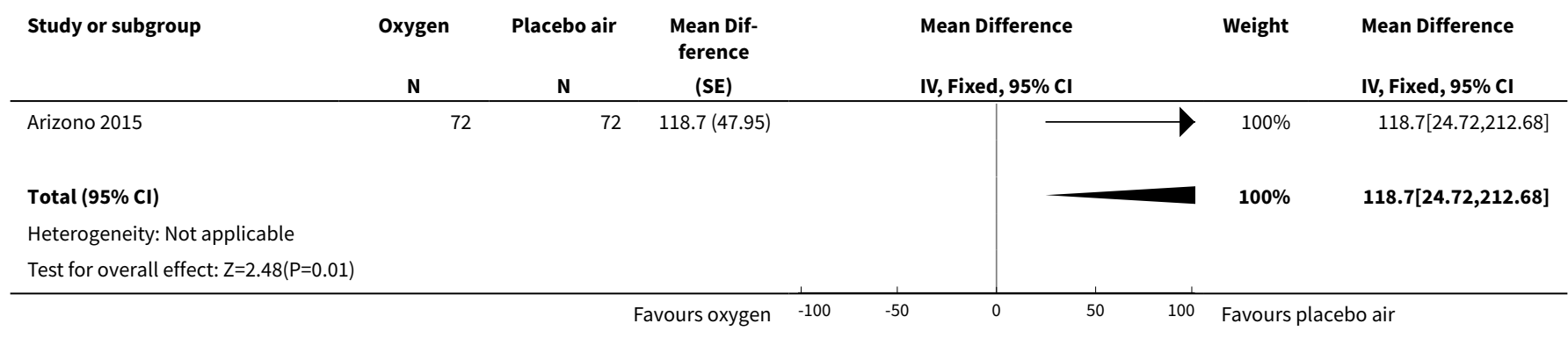

Analysis 1.6. Comparison 1 Ambulatory oxygen versus air, Outcome 6 Minimum saturations at 6MWT (\%).

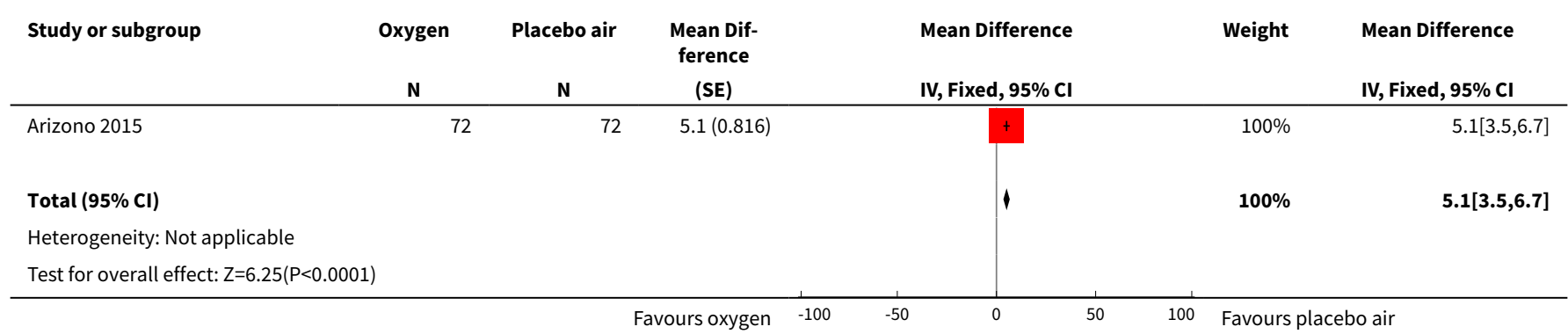

\section{AP PEN DICES}

\section{Appendix 1. MEDLINE (Ovid) search strategy}




\section{1. exp Lung Diseases, Interstitial/}

\section{2. exp Pulmonary Fibrosis/}

3. (interstitial\$ adj3 (lung\$ adj3 disease\$)).tw.

4. (interstitial\$ adj3 (fibros\$ or pneumonitis or pneumonia or pneumopathy)).tw.

5. (diffuse $^{\star}$ adj3 parenchymal $\left.{ }^{\star}\right)$.tw.

6. alveolitis.tw.

7. exp Bronchiolitis Obliterans/ or (bronchiolitis adj3 obliterans).tw.

8. (goodpasture\$ adj3 syndrome\$).tw.

9. granulomatosis.tw.

10. exp Histiocytosis/ or histiocytosis\$.tw.

11. exp Pneumoconiosis/ or pneumoconiosis.tw. or pneumokoniosis.tw. or pneumonoconiosis.tw.

12. bagassosis.tw.

13. (pulmonary\$ adj3 sarcoid\$).tw.

14. (pulmonary\$ adj3 fibros\$).tw.

15. (wegener\$ adj3 granuloma\$).tw.

16. (lung\$ adj3 purpura).tw.

17. ((bird\$ or farmer\$ or pigeon\$ or avian\$ or budgerigar\$) adj3 (lung\$ or disease\$)).tw.

18. (asbestosis or byssinosis or siderosis or silicosis or berylliosis or anthracosilicosis or silicotuberculosis).tw.

19. or/1-18

20. exp Scleroderma, Systemic/

21. scleroderma.tw.

\section{2. exp Rheumatic Diseases/}

23. rheumatic\$.tw.

24. or/20-23

25.24 and (lung\$ or pulmonary\$ or respiratory\$).tw.

\section{19 or 25}

27. Oxygen/ad, tu [Administration \& Dosage, Therapeutic Use]

28. exp Oxygen Inhalation Therapy/ 
(Continued)

29. (oxygen\$ adj3 (therap\$ or ambulat\$ or portable\$ or short\$ or burst\$ or inhal\$)).tw.

30. (oxygen\$ adj5 (palliative\$ or symptom\$ or exercis\$)).tw.

31. Ambulatory Care/

32. or/27-31

33. 26 and 32

34. (controlled clinical trial or randomised controlled trial).pt.

35. (randomised or randomised).ab,ti.

36. placebo.ab,ti.

37. dt.fs.

38. randomly.ab,ti.

39. trial.ab,ti.

40. groups.ab,ti.

41. or $/ 34-40$

42. Animals/

43. Humans/

44. 42 not (42 and 43)

45.41 not 44

46.33 and 45

Appendix 2. CENTRAL (CRS Online) search strategy

\begin{tabular}{|c|c|}
\hline$\# 1$ & MESH DESCRIPTOR Lung Diseases, Interstitial EXPLODE ALL TREES \\
\hline \#2 & MESH DESCRIPTOR Pulmonary Fibrosis EXPLODE ALL TREES \\
\hline \#3 & ((interstitial ${ }^{\star}$ NEAR3 (lung* NEAR3 disease*))):TI,AB,KY \\
\hline \#4 & ((interstitial ${ }^{*}$ NEAR3 (fibros* ${ }^{*}$ or pneumonitis or pneumonia or pneumopathy))):TI,AB,KY \\
\hline \#5 & (diffuse $^{\star}$ adj3 parenchymal ${ }^{\star}$ ):TI,AB,KY \\
\hline \#6 & alveolitis:TI,AB,KY \\
\hline \#7 & MESH DESCRIPTOR Bronchiolitis Obliterans EXPLODE ALL TREES \\
\hline
\end{tabular}




\begin{tabular}{|c|c|}
\hline \#8 & (bronchiolitis NEAR3 obliterans):TI,AB,KY \\
\hline \#9 & (goodpasture $^{\star}$ NEAR3 syndrome*):TI,AB,KY \\
\hline \#10 & granulomatosis:TI,AB,KY \\
\hline \#11 & histiocytosis*:TI,AB,KY \\
\hline$\# 12$ & (pneumoconiosis or pneumokoniosis or pneumonoconiosis):TI,AB,KY \\
\hline$\# 13$ & bagassosis:TI,AB,KY \\
\hline \#14 & 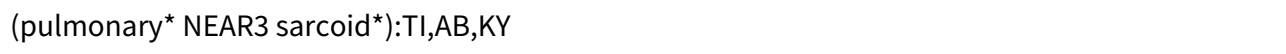 \\
\hline \#15 & (pulmonary ${ }^{\star}$ NEAR3 fibros ${ }^{\star}$ ):TI,AB,KY \\
\hline \#16 & (wegener* NEAR3 granuloma*):TI,AB,KY \\
\hline$\# 17$ & (lung* NEAR3 purpura):TI,AB,KY \\
\hline \#18 & (((bird* or farmer* or pigeon* or avian* or budgerigar* $\left.{ }^{\star}\right)$ NEAR3 (lung* or disease* $\left.\left.)\right)\right): T I, A B, K Y$ \\
\hline \#19 & $\begin{array}{l}\text { (asbestosis or byssinosis or siderosis or silicosis or berylliosis or anthracosilicosis or silicotubercu- } \\
\text { losis):TI,AB,KY }\end{array}$ \\
\hline \#20 & $\begin{array}{l}\# 1 \text { OR \#2 OR \#3 OR \#4 OR \#5 OR \#6 OR \#7 OR \#8 OR \#9 OR \#10 OR \#11 OR \#12 OR \#13 OR \#14 OR \#15 } \\
\text { OR \#16 OR \#17 OR \#18 OR \#19 }\end{array}$ \\
\hline
\end{tabular}

\begin{tabular}{|c|c|}
\hline \#21 & MESH DESCRIPTOR Scleroderma, Systemic EXPLODE ALL TREES \\
\hline \#22 & scleroderma:TI,AB,KY \\
\hline \#23 & MESH DESCRIPTOR Rheumatic Diseases EXPLODE ALL TREES \\
\hline \#24 & rheumatic*:TI,AB,KY \\
\hline \#25 & \#21 OR \#22 OR \#23 OR \#24 \\
\hline \#26 & \#25 AND (lung* or pulmonary* or respiratory ${ }^{\star}$ ) \\
\hline \#27 & \#20 OR \#26 \\
\hline \#28 & MESH DESCRIPTOR Oxygen EXPLODE ALL TREES WITH QUALIFIERS AD,TU \\
\hline \#29 & MESH DESCRIPTOR Oxygen Inhalation Therapy EXPLODE ALL TREES \\
\hline \#30 & $\left(\left(\right.\right.$ oxygen $^{\star}$ NEAR3 $\left(\right.$ therap $^{\star}$ or ambulat ${ }^{\star}$ or portable or short* $^{\star}$ or burst ${ }^{\star}$ or inhal $\left.\left.\left.{ }^{\star}\right)\right)\right): \mathrm{TI}, \mathrm{AB}, \mathrm{KY}$ \\
\hline \#31 & $\left(\left(\right.\right.$ oxygen $^{\star}$ NEAR5 (palliative* or symptom ${ }^{\star}$ or exercis $\left.\left.\left.{ }^{\star}\right)\right)\right): T I, A B, K Y$ \\
\hline \#32 & MESH DESCRIPTOR Ambulatory Care EXPLODE ALL TREES \\
\hline \#33 & \#28 OR \#29 OR \#30 OR \#31 OR \#32 \\
\hline \#34 & \#27 AND \#33 \\
\hline
\end{tabular}




\title{
Appendix 3. EMBASE (Ovid) search strategy
}

\author{
1. exp interstitial lung disease/
}

2. exp lung fibrosis/

3. (interstitial\$ adj3 (lung\$ adj3 disease\$)).tw.

4. (interstitial\$ adj3 (fibros\$ or pneumonitis or pneumonia or pneumopathy)).tw.

5. $\left(\right.$ diffuse $^{\star}$ adj3 parenchymal $\left.{ }^{\star}\right)$.tw.

6. alveolitis.tw.

7. (bronchiolitis adj3 obliterans).tw.

8. (goodpasture\$ adj3 syndrome\$).tw.

9. granulomatosis.tw.

10. histiocytosis\$.tw.

11. (pneumoconiosis or pneumokoniosis or pneumonoconiosis).tw.

\section{2. bagassosis.tw.}

13. (pulmonary\$ adj3 sarcoid\$).tw.

14. (pulmonary\$ adj3 fibros\$).tw.

15. (wegener\$ adj3 granuloma\$).tw.

16. (lung\$ adj3 purpura).tw.

17. ((bird\$ or farmer\$ or pigeon\$ or avian\$ or budgerigar\$) adj3 (lung\$ or disease\$)).tw.

18. (asbestosis or byssinosis or siderosis or silicosis or berylliosis or anthracosilicosis or silicotuberculosis).tw.

19. or/1-18

\section{0. exp systemic sclerosis/}

21. scleroderma.tw.

\section{2. exp rheumatic disease/}

23. rheumatic\$.tw.

\section{4. or/20-23}

25.24 and (lung\$ or pulmonary\$ or respiratory\$).tw.

\section{19 or 25}


(Continued)

27. oxygen/ct, ad, cb, cm, cr, do, it, dt, to, ih, th [Clinical Trial, Drug Administration, Drug Combination, Drug Comparison, Drug Concentration, Drug Dose, Drug Interaction, Drug Therapy, Drug Toxicity, Inhalational Drug Administration, Therapy]

28. exp oxygen therapy/

29. (oxygen\$ adj3 (therap\$ or ambulat\$ or portable\$ or short\$ or burst\$ or inhal\$)).tw.

30. (oxygen\$ adj5 (palliative\$ or symptom\$ or exercis\$)).tw.

31. exp ambulatory care/

32. or/27-31

33. 26 and 32

34. Randomized Controlled Trial/

35. randomization/

36. controlled clinical trial/

37. Double Blind Procedure/

38. Single Blind Procedure/

39. Crossover Procedure/

40. (clinica\$ adj3 trial\$).tw.

41. ((singl\$ or doubl\$ or trebl\$ or tripl\$) adj3 (mask\$ or blind\$ or method\$)).tw.

42. exp Placebo/

43. placebo\$.ti,ab.

44. random\$.ti,ab.

45. ((control\$ or prospectiv\$) adj3 (trial\$ or method\$ or stud\$)).tw.

46. (crossover\$ or cross-over\$).ti,ab.

47. or/34-46

48. exp animals/ or exp invertebrate/ or animal experiment/ or animal model/ or animal tissue/ or animal cell/ or nonhuman/

49. human/ or normal human/ or human cell/

50.48 and 49

51.48 not 50

52.47 not 51

53.33 and 52 


\section{Appendix 4. Cochrane Airways Group Specialised Register search strategy}

\section{\#1 ILD:MISC1}

\#2 MeSH DESCRIPTOR Oxygen

\#3 MeSH DESCRIPTOR Oxygen Inhalation Therapy Explode All

\#4 (oxygen ${ }^{\star}$ NEAR3 (therap ${ }^{\star}$ or ambulat ${ }^{\star}$ or portable ${ }^{\star}$ or short ${ }^{\star}$ or burst ${ }^{\star}$ or inhal ${ }^{\star}$ ))

\#5 (oxygen ${ }^{\star}$ NEAR5 (palliative* or symptom ${ }^{\star}$ or exercis $\left.{ }^{\star}\right)$ )

\#6 MeSH DESCRIPTOR Ambulatory Care

\#7 \#2 or \#3 or \#4 or \#5 or \#6

\#8 \#1 and \#7

\section{CONTRIBUTIONS OFAUTHORS}

CS initiated and developed the protocol, retrieved papers and extracted data.

LS and CS performed the literature searches.

CS and HA screened the titles and abstracts of the literature search results.

CS and ABM screened the retrieved papers against the eligibility criteria and appraised the quality of the included studies.

$\mathrm{CS}, \mathrm{ABM}$ and $\mathrm{HA}$ wrote the review.

\section{DECLARATIONS OF INTEREST}

CS has no known conflicts of interest to report.

HA has no known conflicts of interest to report.

ABM has no known conflicts of interest to report.

\section{SOURCES OF SUPPORT}

\section{Internal sources}

- The review authors declare that they received no funding for this systematic review, Other.

\section{External sources}

- The review authors declare that they received no funding for this systematic review, Other.

\section{DIFFERENCES BETWEEN PROTOCOL AND REVIEW}

We did not identify any studies for inclusion that examined short burst oxygen in ILD, therefore we were unable to examine this. There were insufficient studies to allow us to perform quantitative/meta-analysis. There are no other differences between the protocol and this review.

\section{N DEX TERMS}

\section{Medical Subject Headings (MeSH)}

Ambulatory Care [methods]; Dyspnea [therapy]; Exercise Tolerance; Idiopathic Pulmonary Fibrosis [ ${ }^{\star}$ therapy]; Lung Diseases, Interstitial [ ${ }^{*}$ therapy]; Oxygen Inhalation Therapy [ ${ }^{*}$ methods]; Randomized Controlled Trials as Topic 


\section{MeSH check words}

Humans 